\title{
KANTOR EQUIPOISE: MENYEIMBANGKAN KEHIDUPAN BEKERJA DAN BERKELUARGA
}

\author{
Judelia Kusuma Halim¹), Sidhi Wiguna Teh ${ }^{2)}$ \\ 1)Program Studi S1 Arsitektur, Fakultas Teknik, Universitas Tarumanagara, judeliakh@gmail.com \\ 2)Program Studi S1 Arsitektur, Fakultas Teknik, Universitas Tarumanagara, sidhi@ft.untar.ac.id
}

\begin{abstract}
Abstrak
Saat ini, perilaku generasi milenial dipengaruhi oleh life cycle effect, di mana mereka sedang memulai di tahap kehidupan ketiga dengan fokus meningkatkan karir serta memulai kehidupan berkeluarga. Kantor Equipoise merupakan sebuah wadah bagi mereka untuk dapat mencapai dan menyeimbangkan tujuan kehidupan tersebut. Kantor Equipoise merupakan sebuah kantor yang terbagi menjadi 2 tower dengan penerapan transprogramming dalam desain untuk menghasilkan sebuah program baru yang dapat dialami oleh generasi milenial. Kantor Equipoise didesain dengan bentuk yang melambangkan orang tua dan anaknya sebagai konsep utama yang mencerminkan paduan program di dalamnya. Penambahan second skin ditujukan sebagai elemen yang membantu mengurangi panas dan cahaya yang masuk ke dalam bangunan. Desain pembagian zona didasarkan pada analisis pengguna sesuai dengan metode yang digunakan, bertujuan untuk memberikan pengalaman ruang kepada pengguna maupun pengunjung secara efisien dengan perwujudan arsitektur berupa cahaya, bayangan, material, warna, tekstur, serta bentuk ruang.
\end{abstract}

Kata kunci: Kantor Equipoise; milenial; tahap kehidupan; transprogram

\begin{abstract}
Millennials behavior is currently being shaped by the life cycle effect, in which they are setting out for the third stage of life with a focus on career improvement and starting a family. Equipoise Office is a space facilitating millenials in achieving and balancing those life goals. Equipoise Office is an office building, divided into two-towers by applying transprogramming in design to produce a new program that can be experienced by millennials. It is designed in a form that symbolizes parents and children as the main concept that reflects the mix of programs in it. The second skin is added as an element that aids in reducing heat and light that enters the building. Zone division is designed based on user analysis in accordance with the method used, intended to provide space experience to users and visitors efficiently with the embodiment of architecture in the form of light, shadow, material, color, texture, and shape of space.
\end{abstract}

Keywords: Equipoise office; life cycle; millenials; transprogramming

\section{PENDAhuluAN}

Generasi milenial (Gen - Y) memiliki beberapa karakteristik unik yang membedakan generasi ini dengan generasi sebelumnya yaitu diantaranya merupakan generasi yang multitaskers, individualistis namun juga memiliki hubungan sosial yang baik, materialis, mencintai kebebasan dan fleksibilitas, memiliki pendidikan yang lebih baik dari generasi sebelumnya, mengenal teknologi dengan baik, menyukai perkembangan diri atau karir yang cepat (aktualisasi diri), menyukai inovasi dan kreatif, serta memiliki rasa ingin tahu yang tinggi. Karakteristik milenial ini tentunya membawa pengaruh dan perkembangan serta perubahan cara pandang dalam berbagai aspek.

Perubahan cara pandang milenial terutama terhadap ekonomi, pekerjaan, dan pernikahan juga dipengaruhi oleh life cycle effect. Milenial yang saat ini sedang berada di tahap ketiga dalam kehidupan memiliki fokus untuk meningkatkan karir dan juga memulai kehidupan berkeluarga. Hal ini sesuai dengan data bahwa 54,45\% milenial telah menikah. 


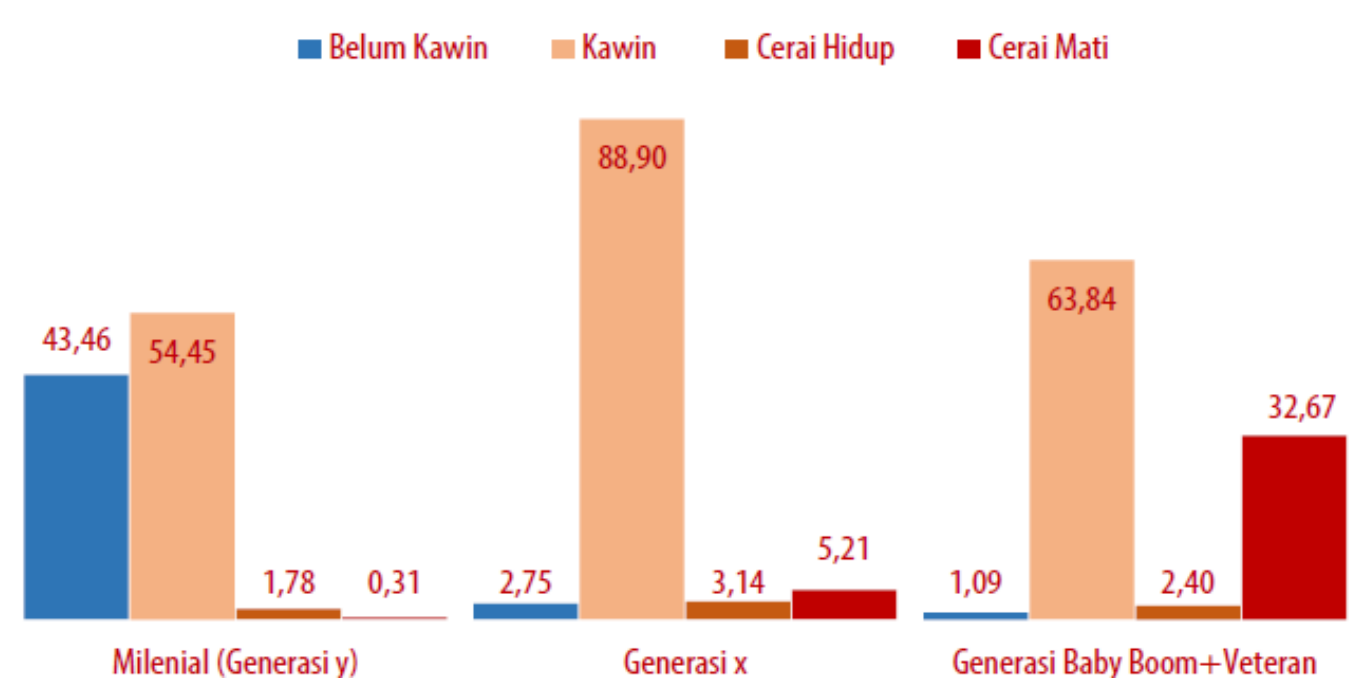

Gambar 1. Persentase Distribusi Penduduk Menurut Generasi dan Status Perkawinan Sumber: Survei Sosial Ekonomi Nasional, BPS, 2017

Kedua hal ini tentunya membuat milenial memiliki masalah tersendiri, yaitu bagaimana dapat menyeimbangkan antara karir serta mulai membangun sebuah keluarga. Diperlukan sebuah ruang bekerja yang dapat meningkatkan produktivitas kerja dan memperhatikan kebutuhan generasi milenial. Keluarga merupakan salah satu motivasi yang dapat meningkatkan produktivitas kerja dan menghilangkan stress yang dialami saat bekerja.

Usulan program "Kantor Equipoise" merupakan jawaban atas isu tersebut, dengan menghadirkan sebuah wadah berupa paduan program antara kantor dan child development center yang dapat menyeimbangkan kehidupan bekerja dan berkeluarga bagi generasi milenial dengan berorientasi terhadap nilai kesejamanan.

\section{KAJIAN LITERATUR}

\section{Generasi Milenial}

Milenial memiliki beberapa definisi yang berbeda mengenai tahun mulainya generasi dan akhir dari generasi ini. Milenial merupakan nama lain dari generasi $Y$, merupakan generasi yang lahir antara tahun 1981-1996 (Pew Research Center, 2019). Generasi milenial sendiri menjadi tren dikarenakan sedang berada di usia produktif, produktivitas dan kreatifitas tinggi, berorientasi pada digital, dan mulai menguasai pasar dunia.

Pada tahun 2020, generasi milenial akan menjadi tulang punggung perekonomian Indonesia, dimana generasi milenial berada pada rentang usia 20-40 tahun yang merupakan usia produktif. Menurut Susenas 2017, jumlah generasi milenial mencapai 88 juta jiwa (33.75\%) dari total penduduk Indonesia.

Menurut riset yang dilakukan Pew Research Center, milenial memiliki cara pandang dan pola pikir yang berbeda dalam berbagai hal termasuk gaya bekerja, pekerjaan, dan pernikahan.

\section{Equipoise}

Kata equipoise merupakan sinonim kata yang memiliki arti keseimbangan. Dinyatakan dalam Kamus Merriam-Webster, equipoise diartikan sebagai "a state of equilibrium". Dalam Bahasa Indonesia, equipoise diartikan sebagai suatu keadaan keseimbangan. Dilihat dari pembedahan etimologi, kata "equipoise" pertama kali muncul pada abad ke-15 yang berasal dari penggabungan dua kata "equal" dan "poise" menjadi equipoise. Pada awalnya yaitu di abad ke-15 kata "poise" sendiri memiliki arti "weight, balance, consideration" yang kemudian seiring perkembangan zaman mulai didefinisikan sebagai keseimbangan. 


\section{Kantor}

Secara etimologis, kantor berasal dari bahasa Belanda yaitu Kantoor yang artinya ruangan tempat bekerja, tempat instansi dan lain-lain. Lalu jika dalam bahasa Inggris berasal dari kata Office yang artinya tempat untuk memberikan pelayanan, ruang tempat bekerja ataupun posisi. Kantor memiliki beberapa definisi, berikut merupakan definisi kantor menurut para ahli:

a. Kantor adalah setiap tempat yang biasanya dipergunakan untuk melaksanakan pekerjaan tatausaha (Moekijat, 1997).

b. Kantor adalah unit organisasi yang terdiri atas tempat, staf personnel, dan operasi ketatausahaan, guna membantu pimpinan (Atmosudirdjo, 1982).

c. Kantor adalah fungsi dimana sistem, prosedur, dan orang-orang yang saling bergantung bekerja untuk mengolah salah satu informasi sumber daya perusahaan yang paling vital (Kallaus \& Keeling, 1991).

\section{Child Development Center}

Child development center adalah pusat pengembangan anak dengan umur 6 minggu hingga 10 tahun dengan fokus pengembangan fisik dan mental anak. Orang tua biasanya menitipkan anak mereka di child development center untuk mengembangkan kemampuan anak secara maksimal di masa awal kanak-kanak dan biasanya memilih child development center yang dekat dengan kantor mereka bekerja. (American Academy of Pediatrics, American Public Health Association, National Resource Center for Health and Safety in Child Care and Early Education, 2011).

\section{Life Cycle}

Life cycle diartikan sebagai konfigurasi unik dari variable-variabel yang berhubungan dengan konteks penyusunan, strategi dan struktur (Hanks, 1990). Dalam kehidupan manusia, manusia melewati beberapa fase kehidupan yang berbeda dan setiap fase atau tahap kehidupan memiliki karakteristik tersendiri (Kelbren, 2018). Kehidupan manusia dibagi menjadi 4 tahap atau fase kehidupan, yaitu (Kelbren, 2018) :

a. Stage I: Programming \& Guidance. Play, Imitation, and Education

Birth - Infancy - Childhood-Adolescence

Pada tahap pertama yang menjadi fokus adalah edukasi, semua yang berkaitan dengan pembelajaran yang menjadi dasar dalam kehidupan. Untuk dapat melewati tahap ini harus mulai melepaskan keinginan untuk mendapat persetujuan dari orang lain dan mulai bertindak untuk diri sendiri.

b. Stage II : Power \& Competition. Self-Discovery, Enterprise \& Aventurousness

Adolescence - Early Adulthood - Adulthood

Pada tahap kedua yang menjadi fokus adalah eksplorasi, kerja keras, dan penemuan jati diri. Dalam tahap ini, adanya penerapan keahlian yang telah dipelajari pada tahap sebelumnya dan dapat melewati tahap ini dengan adanya kesadaran untuk selektif dalam mengambil tindakan.

c. Stage III: Consistency \& New Horizons. Dedication, Contemplation \& Benevolence Adulthood - Midlife - Mature Adulthood

Pada tahap ketiga yang menjadi fokus adalah pertumbuhan karir dan pembangunan serta pengembangan keluarga baru. Dalam tahap ini, dimulainya sebuah keluarga dan memulai sebuah life cyle baru yaitu dengan mempunyai anak, melewati tahap ini dengan merealisasikan visi dan mencapai apa yang diinginkan.

d. Stage IV: Times Recollection. Retirement, Wisdom \& Renunciation Late Adulthood - Death

Pada tahap keempat yang menjadi fokus adalah menemukan arti kehidupan, memastikan peninggalan diturunkan untuk generasi berikutnya, mengajari dan membantu mereka untuk melewati tahapan kehidupan dengan baik. 


\section{Behavioral Architecture}

Hal yang harus diperhatikan dalam merancang bangunan terutama dalam Behavioral Architecture supaya peran bangunan dapat berfungsi sebagai suatu pelayanan sosial maka elemen-elemen yang harus dipertimbangkan yaitu (Heimsath, 1998) :

a. Kegiatan sosial yang ditampung dalam bangunan

b. Fleksibilitas yang dibutuhkan pada tiap kegiatan

c. "Kegiatan-kegiatan" yang mempengaruhi atau dipengaruhi

d. Latar belakang dan sasaran pengguna ruang

Dari elemen-elemen diatas, bisa didefinisikan behavioral architecture adalah ilmu merancang bangunan yang mengacu kepada aspek-aspek yang mendasar dan terkait dengan sikap dan tanggapan manusia terhadap lingkungannya, bertujuan untuk menciptakan ruang dan suasana tertentu yang sesuai dengan perilaku manusia beserta lingkungan dan budaya masyarakat. Berikut merupakan variabel yang berpengaruh terhadap perilaku manusia, antara lain (Setiawan, 1995) :

a. Ruang

b. Ukuran dan Bentuk

c. Perabot dan Penataannya

d. Warna

e. Suara, Temperatur, dan Pencahayaan

Adanya prinsip-prinsip yang harus dipertimbangkan dalam Arsitektur Perilaku antara lain (Tandal \& Egam, 2011) :

a. Mampu berkomunikasi dengan manusia dan lingkungannya

Dari bangunan yang diamati oleh manusia syarat-syarat yang harus dipenuhi adalah:

a) Pencerminan fungsi bangunan.

b) Menunjukkan skala dan proporsi yang tepat serta dapat dinikmati.

c) Menunjukkan bahan dan struktur yang akan digunakan dalam bangunan

b. Mewadahi aktivitas penghuninya dengan nyaman dan menyenangkan

a) Nyaman secara fisik dan psikis. Nyaman fisik berarti kenyamanan thermal, nyaman psikis akan tercipta rasa senang dan tenang.

b) Menyenangkan dapat dijabarkan dalam beberapa aspek :

- Menyenangkan secara fisik, dapat timbul dengan adanya pengolahan pada bentuk dan ruang yang ada di sekitar.

- Menyenangkan secara psikologis, dapat timbul dengan adanya pemenuhan kebutuhan berkaitan dengan jiwa manusia.

- Menyenangkan secara kultural, dapat timbul dengan adanya penciptaan karya arsitektur yang sudah dikenal oleh masyarakat yang berada di tempat tersebut.

c. Memenuhi nilai estetika, komposisi, dan estetika bentuk.

\section{Sistem Struktur, Interior, dan Fengshui}

Kolom dan balok merupakan sistem struktur rangka yang sering digunakan, struktur rangka dapat menjaga kekuatan, daya tahan, dan stabilitas bangunan. Sistem konstruksi kolom dan balok sering dimanfaatkan dan diolah untuk mendapatkan suasana interior yang menarik, salah satunya dengan menggunakan fengshui sehingga pengguna ruang mendapatkan perfoma kehidupan yang optimal (Yap, 2004).

Sistem konstruksi kolom dan balok yang merupakan struktur bangunan selalu memikul beban yang besar sehingga sebuah bangunan dapat berdiri. Adanya beban yang mengalir pada kolom dan balok menimbulkan getaran sehingga dapat memberikan pengaruh negatif terhadap user yang berada di dekat sistem konstruksi, user yang aktif di ruang tersebut tidak dapat memiliki performa yang baik (Teh, Lianto, \& Trisno, 2018). 
Solusi fengshui dalam arsitektur ini adalah dengan menutup struktur kolom dan balok menggunakan plafon, menyamarkan sudut-sudut kolom dengan dijadikan bagian dari lemari, serta untuk tidak duduk, tidur di bawah dan menghadap struktur kolom dan balok (Teh, Lianto, \& Trisno, 2018).

\section{METODE}

Metode yang digunakan dalam pemilihan tapak adalah mengumpulkan data dan dilakukan analisis data terhadap pusat perkantoran di setiap daerah sebagai acuan awal dalam menentukan kawasan. Kemudian dilakukan analisis makro berdasarkan potensi, zonasi, dan kepadatan bangunan untuk menentukan tapak spesifik.

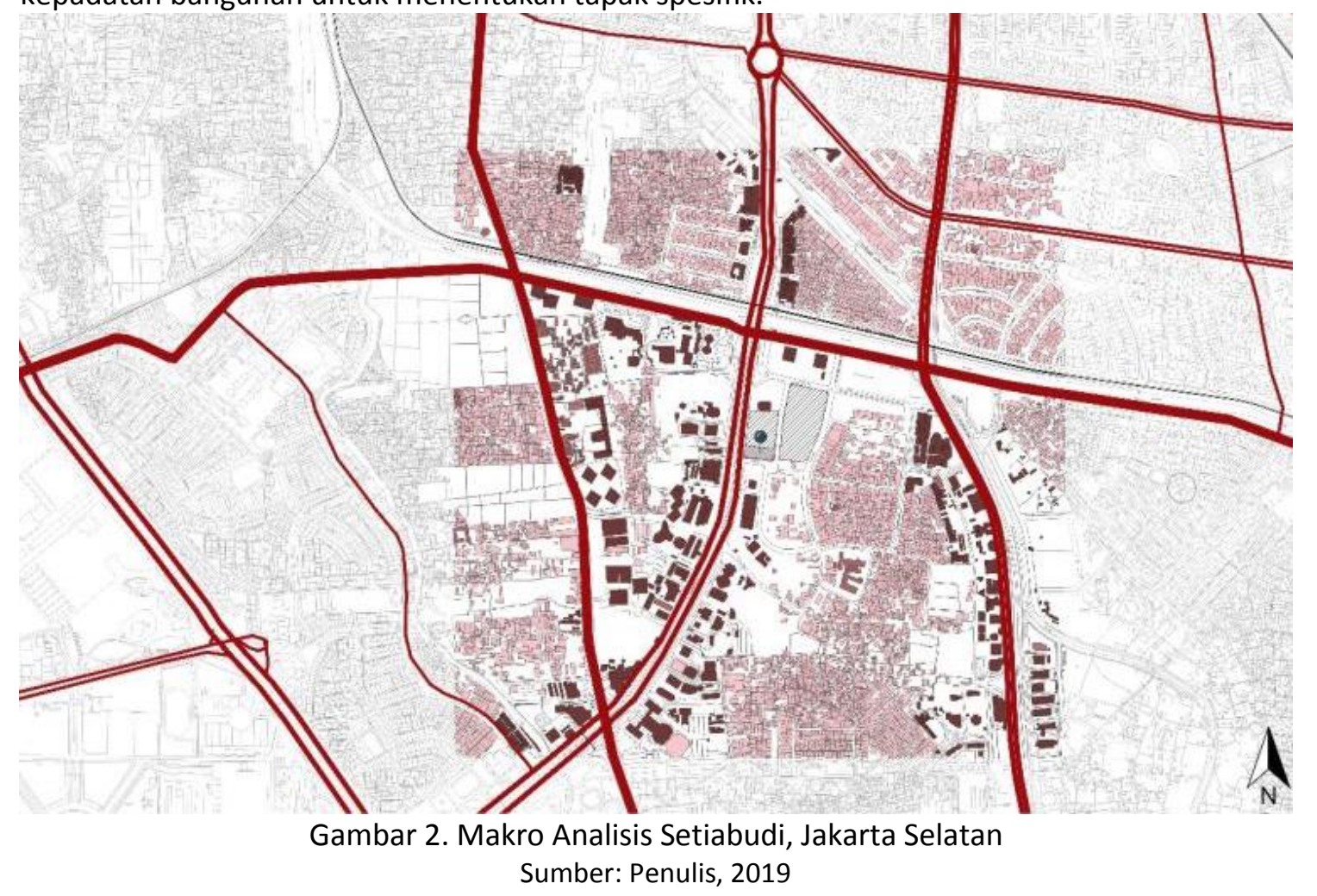

Melihat pola kawasan serta jaringan primer dan sekunder kawasan Setiabudi dari sistem tatanan kawasan. Pemilihan kawasan dimulai dari area yang diarsir hingga tapak terpilih yang ditujukkan dengan garis batas merah dan pin-point biru. Tapak berlokasi di Jl. Setia Budi Barat VII berbatasan langsung dengan Jl. Jenderal Sudirman di sisi barat tapak dan lahan kosong di sisi utara tapak.

Dalam tahap perancangan menggunakan metode transprogramming yaitu metode yang mengkombinasikan dua program yang sifat dan konfigurasi spasialnya berbeda tanpa melihat kecocokannya (Tschumi, 2005) serta menerapkan behavioural architecture, yaitu arsitektur berwawasan perilaku yang bertujuan untuk menciptakan ruang dan suasana yang sesuai dengan perilaku manusia, lingkungan dan budaya masyarakat (Heimsath,1998). Dilakukan kombinasi antara program kantor dan child development center yang memiliki sifat dan konfigurasi spasial yang berbeda dan merupakan program yang digabungkan dengan pertimbangan perilaku manusia khususnya generasi milenial menjadi salah satu aspek yang berpengaruh dalam perancangan proyek. 


\section{DISKUSI DAN HASIL}

Kantor Equipoise yang berlokasi di Setiabudi, Jakarta Selatan berada di daerah pusat perkantoran dan berbatasan langsung dengan Jl. Jendral Sudirman. Proyek dengan luas tapak $\pm 5618 \mathrm{~m}^{2}$ memiliki program utama berupa kantor (55\%), program kedua berupa child development center (25\%), program pendukung berupa restoran (10\%), dan servis (10\%).

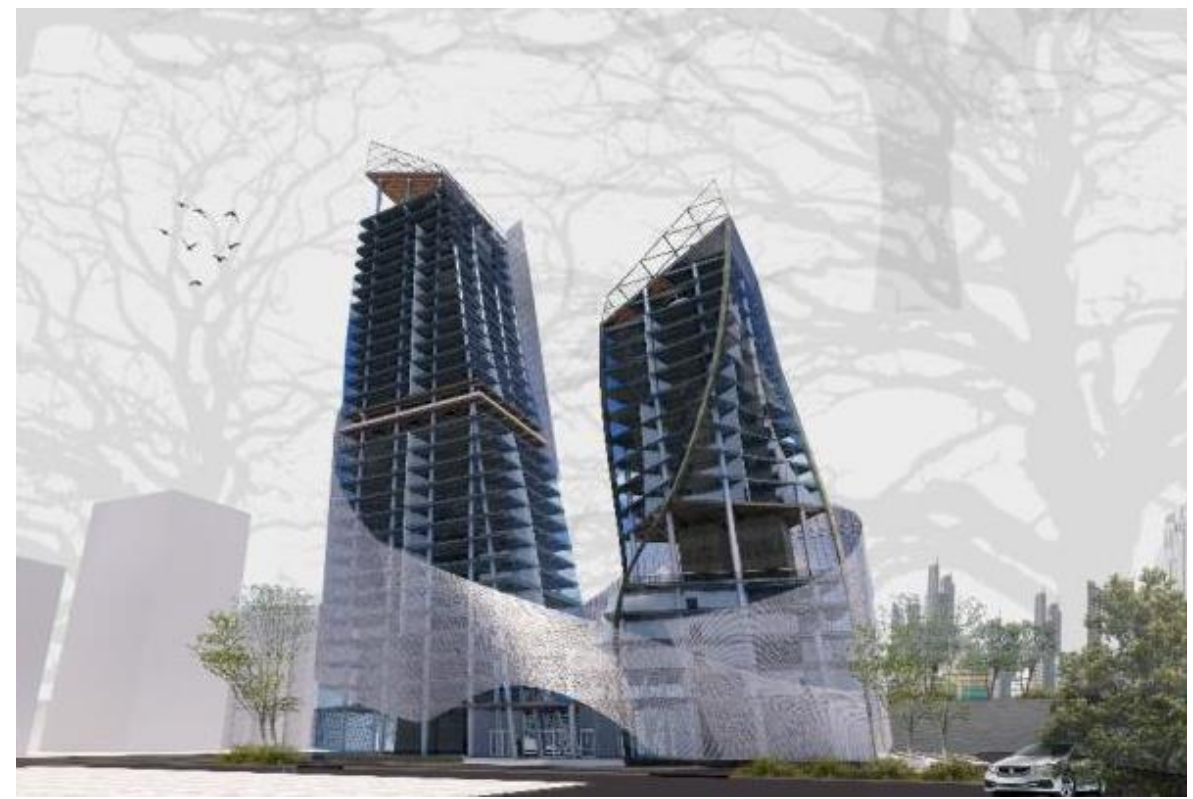

Gambar 3. Perspektif Eksterior

Sumber: Penulis, 2019

Pembagian program bangunan dilakukan secara vertikal maupun horizontal dengan memperhatikan kenyamanan dan efisiensi bagi pengguna. Adanya ruang-ruang transisi antar program untuk membuat program saling terhubung namun masih memiliki area program yang jelas.

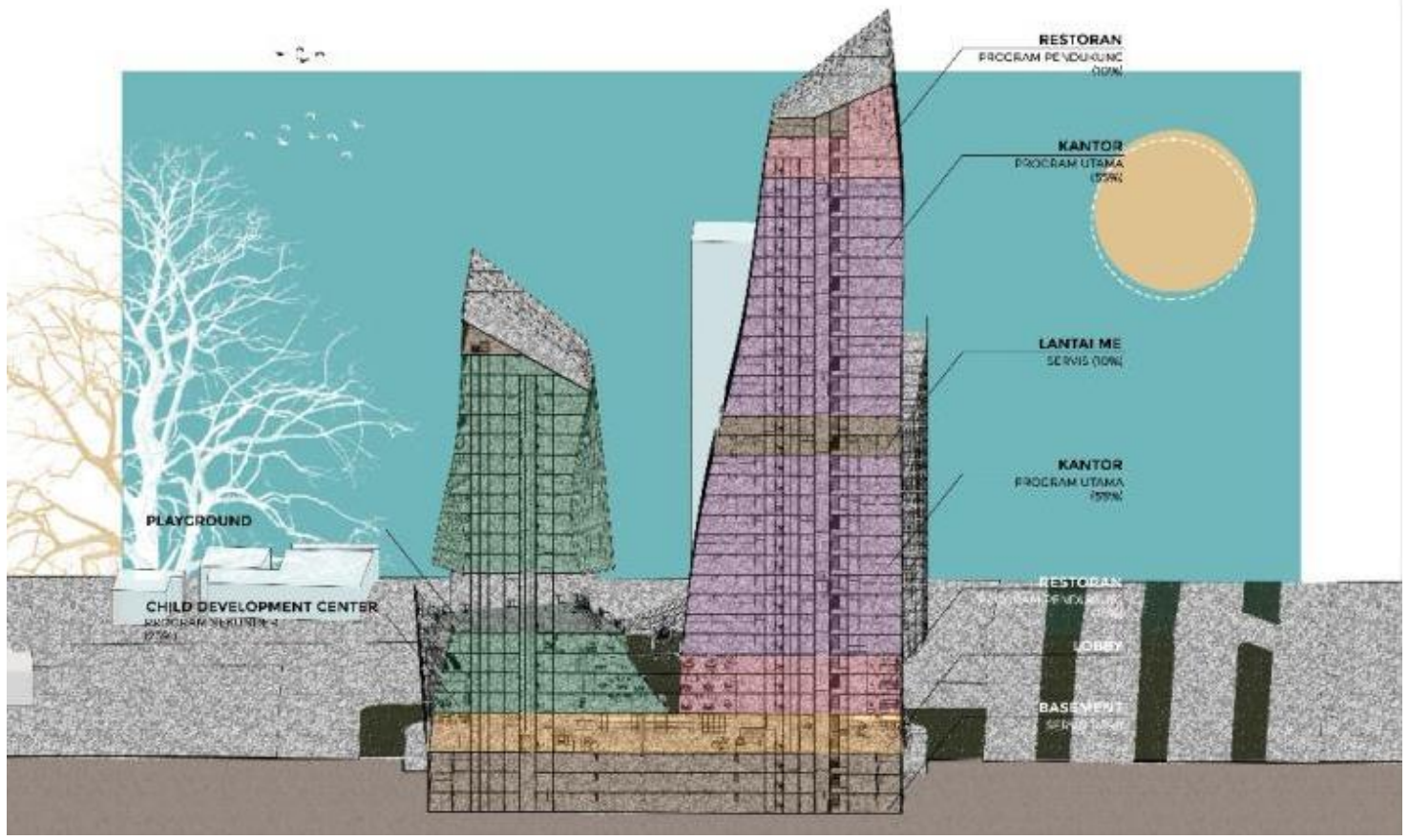

Gambar 4. Diagram Program Bangunan

Sumber: Penulis, 2019 
Berikut merupakan suasana ruang yang dihasilkan dari hasil desain baik dari eksterior maupun interior bangunan.

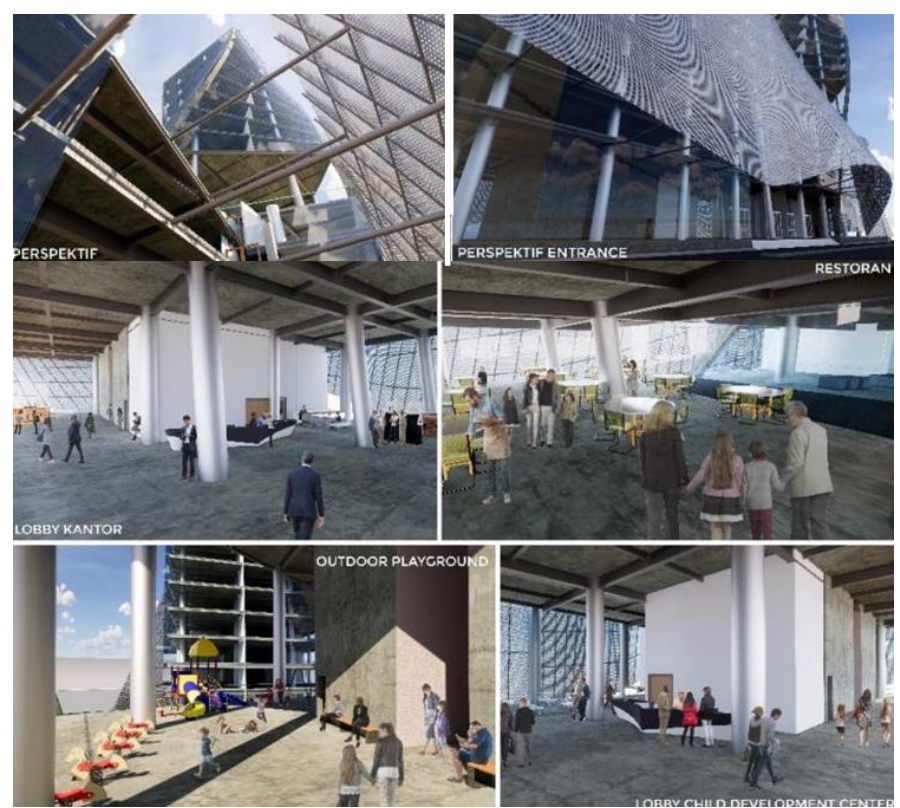

Gambar 5. Suasana Eksterior \& Interior Bangunan

Sumber: Penulis, 2019

Warna yang digunakan didominasi oleh warna putih dan abu-abu serta menggunakan taman (warna hijau), penggunaan material kayu, dan kaca sebagai penyeimbang. Warna monokrom sengaja dipilih untuk menonjolkan ruang dalam dari warna-warni perabot yang digunakan terutama pada program child development center.

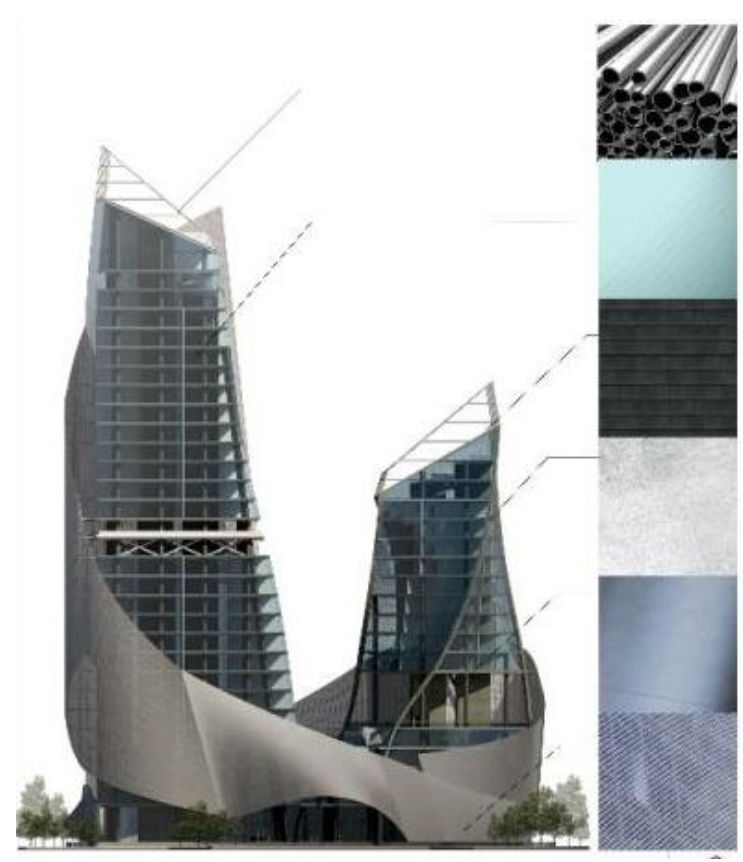

Gambar 6. Color Scheme Material

Sumber: Penulis, 2019 


\section{KESIMPULAN DAN SARAN}

Kantor Equipoise berperan sebagai wadah yang mampu menyeimbangkan kehidupan bekerja dan berkeluarga seseorangan dengan penerapan transprogramming dalam susunan program di dalamnya untuk menghadirkan sebuah program baru dengan memperhatikan efisiensi dan kenyamanan pengguna.

\section{REFERENSI}

American Academy of Pediatrics, American Public Health Association, National Resource Center for Health and Safety in Child Care and Early Education. (2011). Caring for our children: National health and safety performance standards; Guidelines for early care and education programs. (Edisi ke-3). Elk Grove Village, IL: American Academy of Pediatrics.

Armstrong, T. (2008). The Human Odyssey: Navigating the Twelve Stages of Life. New York: Sterling.

Atmosudirdjo, S. P. (1982). Kesekretarisan dan Administrasi Perkantoran. Jakarta: Ghalia Indonesia.

Badan Pusat Statistik. (2018). Statistik Gender Tematik: Profil Generasi Milenial Indonesia. Jakarta: Kementerian Pemberdayaan Perempuan dan Perlindungan Anak.

Cohen, N. (2013). Why America Never Had Universal Child Care. Retrieved February 10, 2019, from https://newrepublic.com/article/113009/child-care-america-was-very-closeuniversal-day-care.

Duffy, B., Shrimpton, H., \& Clemence, M. (2017). Millennial Myths and Realities. UK: Ipsos MORI.

Fry, R. (2016). Millennials projected to overtake Baby Boomers as America's largest generation. Retrieved January 7, 2019, from http://www.pewresearch.org/facttank/2018/03/01/millennials-overtake-baby-boomers/.

Goldman, S. (2017). Millennials Coming of Age. Retrieved January 10, 2019, from https://www.goldmansachs.com/insights/archive/millennials/.

Hamill, J. (2016). Millennials are lazy, self-indulgent and lack the initiative to be successful, warns lifestyle guru Martha Stewart. Retrieved February 10, 2019, from https://www.thesun.co.uk/news/1436480/millennials-are-lazy-self-indulgent-and-lackthe-initiative-to-be-successful-warns-lifestyle-guru-martha-stewart/.

Hanks, S. (1990). An Empirical Examination of the Organizational Life Cycle in High Technology Firms. Doctoral Dissertation : University of Utah.

Heimsath, C. (1998). Arsitektur dari segi Perilaku. Bandung: Intermatra.

Kallaus, N. F., dan Keeling, B.L. (1991). Administrative Office Management Tenth Edition. Nashville: South Western Publishing.

Kelbren, C. A. (2018). Personalities or Identity: Which Shapes Your Life?. Bloomington: LifeRich Publishing.

Lopez, N. (2017). Gen Y: Millennials in Architecture. Retrieved January 11, 2019, from https://medium.com/studiotmd/gen-y-millennials-in-architecture-476e9839321b.

Mahnke, F., \& Mahnke, R. H. (1993). Color \& Light in Man Made Environment. New York: Van Nostrand Reinhold.

Merriam-Webster. (1981). Webster's New Collegiate Dictionary. London: MerriamWebster, Inc.

Moekijat. (1997). Administrasi Perkantoran. Bandung: Mandar Maju.

Pew Research Center. (2015). The Generations Defined. Retrieved January 12, 2019, from www.pewresearch.org/fact-tank/2015/05/11/millennials-surpass-gen-xers-asthelargest-generation-in-u-s-labor-force/ft_15-05-11_millennialsdefined/.

Raymond, S., \& Cunliffe, R. (2000). Tomorrow's Office: Creating Effective and Humane Interiors. London: Taylor \& Francis Ltd.

Rees, R. P., \& Willan, J. (2006). Early Years Education. UK: Routledge. 
Setiawan, H. (1995). Arsitektur Lingkungan Dan Perilaku. Yogyakarta: Direktorat Jendral Pendidikan.

Tandal, A.N., \& Egam, P. P. (2011). Arsitektur Berwawasan Perilaku (Behaviorisme), 8(1), 53-67.

Teh, S.W., Lianto, F., \& Trisno, R. (2018). The Impact of Column and Beam Construction SysteM to Interior Design Layout According to Fengshui, 09(13), 1822-1828.

Tschumi, B. (2005). Event-Cities 3 : Concept vs. Context vs. Content. US: MIT Press.

Twenge, J.M. \& Campbell, S. M. (2013). Managing the new Workforce: International Perspectives on the Millennial Generation. UK: Edward Elgar Publishing.

U.S. Department of Veterans Affairs. (2016). Chapter 420: Childcare / Development Center. Washington DC: U.S. Department of Veterans Affairs.

U.K. Board of Education. (2006). "The Development of Infant Schools and of Separate Nursery Schools from 1905 to the Present Time". London: HM Stationery Office.

Vespa, J. (2017). The Changing Economics and Demographics of Young Adulthood: 1975-2016. US: US Census Bureau.

Yap, J. (2004). Stories and Lessons on Feng Shui. Kuala Lumpur: Mastery Academy of Chinese Metaphysics Sdn. Bhd. 
